DOI : https://doi.org/10.31539/leea.v3i2.1010

\title{
USING VOCABULARY SELF-COLLECTION STRATEGY (VSS) TO IMPROVE MASTERY STUDENT'S VOCABULARY
}

\author{
Putri Anita Simbolon ${ }^{1}$ \\ Universitas Prima Indonesia \\ Feber Anggelina Br Bangun ${ }^{2}$ \\ Universitas Prima Indonesia \\ Sumianti Magdalena Pardede ${ }^{3}$ \\ Universitas Prima Indonesia \\ Jelinta Br Tarigan ${ }^{4}$ \\ Universitas Prima Indonesia \\ Sri Ninta Br Tarigan ${ }^{5}$ \\ Universitas Prima Indonesia \\ putrianitasimbolon6@gmail.com ${ }^{1}$
}

Submit, 05-12-2019 Accepted, 30-01-2020 Publish, 12-02-2020

\begin{abstract}
The research aims to know that Vocabulary Self-collection Strategy (VSS) can improve students' vocabulary mastery and to find out how far Vocabulary SelfCollection Strategy (VSS) can be useful for the students' vocabulary mastery at the second-grade students of SMP Sinar Husni Medan. The methodology of this research used Classroom Action Research. It was conducted on a two-cycle. In analyzing the data, the researcher used quantitative data. The implementation of Vocabulary Selfcollection Strategy (VSS) in teaching vocabulary at eight grade students was successful. It can be seen from the progress of the mean score in cycle I to cycle II. Mean score in a period I $71.20 \%$ and rating in cycle II $78.80 \%$. The implementation Vocabulary Self-collection Strategy (VSS) as a learning strategy was not only increasing students' mean score but also increase students' motivation and behavior. The students were more interested, happy, and active in teaching-learning English, especially vocabulary. Based on the result above, it could be concluded that Vocabulary Self - Collection Strategy (VSS) improved their students' vocabulary mastery.
\end{abstract}

Keywords: vocabulary mastery, vocabulary self-collection strategy (VSS) 


\section{INTRODUCTION}

Mastering English is not as easy as taking something for granted. Learners have to go through many steps and parts of learning. One of those parts is learning and mastering the vocabulary in English. One aspect of language which plays a significant role in English ability is vocabulary. According to Brown (2010) says that words are the basic building blocks of language; names are used to create sentences, more large paragraphs, and whole texts. After observation, especially in class VIII-A, the researcher found some problems from the students. The first, the students still confused with the meaning of the word. Second, they were difficult to remember some names. Third, they are challenging to write the words in the sentences. Fourth, they were also challenging to translate the meaning of a word in sentences. Fifth, the students' motivation in English lesson was still less. The researcher predicted the possible causes of the problems.

The researcher found the factor of why the problem arose. First, mostly students' did not have a dictionary. It made them felt confused about knowing the meaning of words. Second, they rarely practiced speaking the words every day. So, their vocabulary was low. Third, they also did not have the right strategy to remember the words in the learning process. It made them forget many words they have in the learning process. Fourth, sometimes the teacher unclear when explaining the material in the learning process. Based on the description above, the researcher interested in using strategy to teaching vocabulary used Vocabulary Self-Collection Strategy (VSS) to improve the students' vocabulary mastery. According to Residence, Bean, and Baldwin (in Lester and Elliot, 2002) states that the purpose of the Vocabulary Self-Collection Strategy is to help students generate a list of words to explore and learned and to use their prior knowledge and interests to enhance their vocabulary. This strategy can be used to stimulate growth in word knowledge.

In this study, the researcher used five references to previous research. The first study was conducted by Muttahidah (2012) she found that the students' vocabulary mastery achievement increased significantly after being taught by using Vocabulary Card. It was proven by the improvement of students' vocabulary mastery scores from pre-test up to post-test. The second study was conducted by Fatonah (2015) the research findings showed that reading comprehension of most students improved after the Vocabulary Self-Collection Strategy was used in the teaching and learning process. It was indicated by the increase of the mean of students reading comprehension scores in the pre-test and post-test (58.9 to 78.0) and several other improvements, i.e., improve the students' interest in learning English texts, facilitate the students in defining the unfamiliar words based on the context of the book, and 
improve interaction both among the students by employing small group discussion and between the students and the teacher during the class.

Artoni (2013) explained that the Vocabulary Self-Collection Strategy (VSS) is a strategy that is guiding students to make a list of vocabulary. List of vocabulary depends on unfamiliar, and interest words of students"e perception, and this strategy can increase students" vocabulary. This strategy is appropriate to apply before going to teach reading. The advantages of Vocabulary Self-Collection Strategy (VSS) are to increase students ${ }^{\text {ee }}$ vocabulary and suitable for pre and post-reading and help students determine a purpose for reading. This strategy also can motivate the students by selecting the new word that makes them active in reading

Juwita (2013) used Vocabulary Self-Collection as a strategy to teach vocabulary. Vocabulary Self-Collection Strategy (VSS) is an approach to teach vocabulary by using students'ee ability in collecting and generating words list, and it emphasizes the student'se personal experiences and general knowledge. This strategy is started with the assignment for both students and teachers to bring words that they believe whole members of the class should learn. Aisyiyah holds the latest previous study (2015) the result of the survey found that vocabulary mastery of most students improved after the Vocabulary Self-Collection Strategy was used in the teaching and learning process. It was indicated by the increase in the number of students who passed the criteria of success from Pre-Test - Post-Test 1 - Post-Test 2.

The three research that had been conducted above showed that the Vocabulary Self-Collection Strategy (VSS) was successfully implemented to improve the students' vocabulary learning. By basing on those three previous studies, the researcher does want to research in the same field. What makes it different is that in this study, the researcher applies Vocabulary Self-Collection Strategy by attaching the teaching of reading comprehension to solve vocabulary problems that occurred in vocational high school level. Although originally VSS was developed for secondary students (Gregersen, 2007), by looking up the students' English awareness, the researcher conducts a study to improve vocabulary mastery of the students of Vocational High School of Bandung. It was because the researcher thought that the students of class X AK-2 were cooperative to do the strategy. Besides, the researcher intended to invite the students to learn English vocabulary joyfully through an enjoyable reading class. Considering the actions conducted in the previous studies, it was expected that the implementation of VSS in this study would also be successful. 


\section{LITERATURE REVIEW}

The vocabulary self-collection strategy (VSS) is an interactive-learning instructional strategy that promotes word consciousness, as students are actively engaged in identifying essential words from their reading to share with members of their class. The plan was first to introduce by haggard $(1982,1986)$ and since then has been adapted for various grade levels and instructional contexts. Students select words from their readings that are new and interesting, use the background and other resources to determine the meaning of the phrase, and nominate the name to be learned by others in the group or class. Teachers using the VSS (1) model the process of collecting signatures, (2) provide guided practice within reading groups, and other instructional contexts, and (3) offer consistent encouragement to students to use VSS during independent reading. The significant benefits of using VSS are that students engage in their learning, discover how to recognize unfamiliar or exciting words from their texts, develop their vocabularies, and become word conscious. A review of the research on vocabulary instruction conducted by Harmon et al. (2005) led them to claim that struggling readers learn vocabulary when teachers " encourage independent learning by allowing students to self-select terms to be studied. They pointed to VSS as an approach to help students to select and review words that they feel are important to learn. Research conducted by Calderon et al. (2005) with English language learners demonstrated that, in addition to teaching vocabulary before reading, their discourse around the next after reading leads to students' vocabulary development.

Vocabulary Self-Collection Strategy (VSS) According to Residence, Bean, and Baldwin (in Lester \& Elliot, 2002) states that the purpose of Vocabulary SelfCollection Strategy is to help students generate a list of words to explore and learned and to use their prior knowledge and interests to enhance their vocabulary. This strategy can be used to stimulate growth in word knowledge. Because the list is selfgenerative, internal motivation is utilized. This strategy can help students become fascinated with language and thus, increase their enjoyment of the subject. VSS (Vocabulary using Vocabulary Self-Collection Strategy) involves the following steps: 1) Selecting the words 2) Defining the phrase 3) Finalizing the terms list 4) Extending names knowledge According to Stoddard (2006), say that the purpose of the strategy enables the long-term acquisition of vocabulary. Because the students generate both the vocabulary and the meaning from a text they are currently using, not only do they learn the vocabulary in context.

The first research was conducted by Martono \& Asrori (2012) tells that the most common problem is the difficulty of students using grammar, limited 
vocabulary, and pain in spelling correctly. This study used different data collection methods from previous research. The quantitative data were obtained by calculating the score of the test. The researchers used oral text, written tests, and interviews to collect the data. To analyze the qualitative data, the researcher used steps to collect the data, gather the data from the scoring of the class, compare the students' scores, calculate the percentage of the students' scores, make the conclusion.

\section{RESEARCH METHOD}

This researcher used classroom action research $\{C A R\}$ as the research design. Classroom action research is part of a broad movement that has been going on in education, generally for some time. In CAR, there is a cycling term that contains four stages of this research. The four steps are an action plan, implementation action, observation, reflection. The result of one cycle is used to determine the need for the following period until the problem gets solved by strategy.

\section{FINDINGS}

The researcher found that the students' mastery in vocabulary was low. It could be shown in the percentage of the class unsuccess was $47.3 \%$. It meant that the students who failed the vocabulary test on the preliminary study were $47.3 \%$. It said that all students were unsuccessful. (see the table of students' score in Vocabulary test for each cycle) The result of the check-in period one and two was different. It had shown the improvement of the students continuously. The percentage of test 1 in cycle 1 was $71.20 \%$ and in cycle 2 was $78.80 \%$. It showed that the teaching and learning process was successful. The result of students' score percentage also shows the significant improvement that is $78.80 \%$, and that indicated higher than the minimal mastery criterion (70). The researcher concluded that improving students' vocabulary mastery using VSS strategy could increase the student's ability to master vocabulary. It means that developing students' vocabulary mastery using VSS strategy in SMP SINAR HUSNI is successful in the classical category.

Table 1. Table of Students' Score in Vocabulary Test for Each Cycle

\begin{tabular}{lllllll}
\hline No & Student's Name & $\begin{array}{l}\text { Preliminary } \\
\text { Test }\end{array}$ & $\begin{array}{l}\text { Test } \\
\text { (Cycle 1) }\end{array}$ & $\begin{array}{l}\text { Test } \\
\text { Cycle 2) }\end{array}$ & 2( & Mean \\
\hline 1. & Abdul Dimas fares & 40 & 67 & 76 & 61 \\
\hline 2. & Arifin & 56 & 65 & 78 & 66.3 \\
\hline
\end{tabular}




\begin{tabular}{|c|c|c|c|c|}
\hline Bagas syahputra & 50 & 67 & 78 & 65 \\
\hline Egi Santika & 50 & 70 & 75 & 65 \\
\hline Nabila febrianti & 48 & 67 & 77 & 64 \\
\hline M. Rafi irawan & 60 & 70 & 80 & 70 \\
\hline 7. Gisya hadaya s & 45 & 68 & 75 & 62.7 \\
\hline $\begin{array}{ll}\text { 8. } & \text { Kasyfiana }\end{array}$ & 50 & 65 & 80 & 65 \\
\hline 9. $\quad$ Kasyfiani & 50 & 67 & 87 & 68 \\
\hline 10. M. prastyo akbairih & 65 & 70 & 85 & 73.3 \\
\hline 11. M. khadavi & 30 & 75 & 90 & 65 \\
\hline 12. Zuanda & 60 & 67 & 80 & 69 \\
\hline 13. M. alfikri & 40 & 77 & 78 & 65 \\
\hline 14. Alfy Dindo miranti & 40 & 70 & 69 & 59.7 \\
\hline 15. Fika Julia Dewi & 50 & 70 & 90 & 70 \\
\hline $\begin{array}{lll}\text { 16. } & \begin{array}{l}\text { M. risky romo } \\
\text { dhoni }\end{array}\end{array}$ & 50 & 68 & 75 & 64.3 \\
\hline 17. $\begin{array}{l}\text { Dandy maisana } \\
\text { saragih }\end{array}$ & 40 & 67 & 75 & 60.7 \\
\hline 18. M. jonothan & 45 & 60 & 78 & 61 \\
\hline 19. Abdul rojab & 50 & 66 & 80 & 65.3 \\
\hline 20. Aldy Surya & 40 & 76 & 76 & 64 \\
\hline 21. Dewi anggrani & 30 & 75 & 80 & 61.7 \\
\hline 22. Lenoni umaros & 35 & 78 & 80 & 64.3 \\
\hline 23. Yahtya & 40 & 80 & 85 & 68.3 \\
\hline 24. Cheery & 55 & 77 & 80 & 70.7 \\
\hline 25. Rei asahel & 65 & 60 & 67 & 64 \\
\hline 26. Amando Dewi & 50 & 69 & 75 & 64.7 \\
\hline 27. Ikchan $\mathrm{m}$ & 50 & 79 & 80 & 69.7 \\
\hline 28. Haitun nisa & 45 & 77 & 80 & 67.3 \\
\hline 29. Nabila fahrezi & 40 & 78 & 80 & 66 \\
\hline 30. Nina hairani & 40 & 78 & 80 & 66 \\
\hline 31. Jihan baby & 40 & 80 & 80 & 66.7 \\
\hline 32. Intan anastasya & 50 & 70 & 75 & 65 \\
\hline 33. Risma Siregar & 50 & 70 & 75 & 65 \\
\hline 34. $\quad$ Siti aminah & 50 & 78 & 80 & 69.7 \\
\hline TOTAL SCORE & 1599 & 2421 & 2679 & \\
\hline MEAN & 47.03 & 71.20 & 78.80 & \\
\hline
\end{tabular}

From the data above, it could be seen that there were 13 students (38\%) in cycle 1 , passing the minimal mastery criterion $(\geq 70)$. And there were only two students who failed the test or got lower than the minimum mastery criterion. The 
collecting data which was taken from the students' observation sheet and questionnaire could be said that VSS made the students interested. The students were more enthusiastic about learning difficult vocabulary. They looked enjoyable in the class that applied the VSS strategy. After using the VSS strategy, the researcher saw that there were good responses from the students. The students were more enthusiastic about studying English (vocabulary) by using a VSS strategy. Also, it could be used to avoid boredom in the class. In general, the researcher concludes that improving students' vocabulary mastery using a VSS strategy can increase the student's ability to master vocabulary.

\section{DISCUSSION}

Classroom action research was done in two cycles. It was because the researcher found some wanted to achieve the target score. Based on the study, the researcher found some weaknesses and strengths in applying vocabulary selfcollection strategy as a way to improve students' vocabulary mastery.

The researcher found that the students' mastery in vocabulary was low. It could be shown in the percentage of the class unsuccess was $47.3 \%$. It meant that the students who failed the vocabulary test on the preliminary study were $47.3 \%$. It said that all students were unsuccessful. (see the table of students' score in Vocabulary test for each cycle) The result of the check-in period one and two was different. It had shown the improvement of the students continuously. The percentage of test 1 in period 1 was $71.20 \%$, and in period 2 was $78.80 \%$. It showed that the teaching and learning process was successful. The result of students' score percentage also shows the significant improvement that is $78.80 \%$, and that indicated higher than the minimal mastery criterion (70). The researcher concluded that improving students' vocabulary mastery using VSS strategy could increase the student's ability to master vocabulary. It means that developing students' vocabulary mastery using VSS strategy

After the second cycle had finished, the researcher interviewed, but also the collaborator of this research, Sri Murningsih. Collaborator said that by using a vocabulary self-collection strategy, students were interested to learn English, and it helped them to improve their vocabulary mastery. The researcher considered that using a vocabulary self-collection strategy was able to upgrade the eighth-grade os Smp Sinar Husni Medan. It also helped students to improve their vocabulary mastery by themselves; it was also able to motivate students to learn English vocabulary. Conducted by Muttahidah (2012), she found that the students' vocabulary mastery achievement increased significantly after being taught by using Vocabulary Card. It 
was proven by the improvement of students' vocabulary mastery scores from pre-test up to post-test. The second study was conducted by Fatonah (2015) the research findings showed that reading comprehension of most students improved after the Vocabulary Self-Collection Strategy was used in the teaching and learning process. It was indicated by the increase of the mean of students reading comprehension scores in the pre-test and post-test (58.9 to 78.0) and several other improvements, i.e., improve the students' interest in learning English texts, facilitate the students in defining the unfamiliar words based on the context of the book, and improve interaction both among the students by employing small group discussion and between the students and the teacher during the class.

Juwita (2013) used Vocabulary Self-Collection as a strategy to teach vocabulary. Vocabulary Self-Collection Strategy (VSS) is an approach to teach vocabulary by using students ${ }^{\text {'ee }}$ ability in collecting and generating words list, and it emphasizes the student'see personal experiences and general knowledge. This strategy is started with the assignment for both students and teachers to bring words that they believe whole members of the class should learn.

\section{CONCLUSION}

. The researcher concludes that increasing students 'vocabulary mastery using VSS strategy can improve students' ability in mastering vocabulary, and this can be seen from the tests that have been done there are two tests conducted by researchers and the results obtained by researchers from the comparison of the first test and the second test can conclude that in the second test the student's average score improved from the first test. The results of this study with the students' vocabulary test scores can be concluded that the application of VSS in vocabulary teaching for eighth-grade students in SMP Sinar Husni medan increased and can be proven from the progress of the average scores of students in the table that has been made.

\section{REFERENCES}

Aisyiyah, F., Y. (2015). "Improving English Vocabulary Mastery through Vocabulary Self-Collection Strategy of the First Grade Students of Muttawasith at Addirasat Islamiah School Laddua Panarea Pattani South of Thailand." IAIN Tulungagung.

Artoni, S. (2013). "Teaching Reading by Combining Vocabulary Self-Collection Strategy (VSS) and Cubing Strategy at Junior High School." State Islamic University of Sultan Syarif Kasim Riau. 
Brown, H. D. (2010). Language Assessment Principles and Classroom Practices. San Francisco: Pearson Education

Calderón, M., August, D., Slavin, R., Duran, D., Madden, N., \& Cheung, A. (2005). Bring words to life in classrooms with English-language learners. In E. H. Hiebert \& M. L. Kamil (Eds.), Teaching and learning vocabulary: Bringing research to practice (pp. 115-136). Mahwah, NJ: Erlbaum.

Fatonah, S., N.(2015). "Using Vocabulary Self-Collection (VSS) To Improve Reading Comprehension of The Seven Grade Students Of SMPN 4 Kalasan In The Academic Year of 2014/2015". English Departement Faculty of Language and Arts: Yogyakarta State University

Gregersen. (2007). Vocabulary Self-Collection Strategy for primary readers. Texas State University. Available at: Citeseerx.ist.psu.edu. Downloaded on $15^{\text {th }}$ February 2013.

Haggard, M., R. (1982). The Vocabulary Self-Collection Strategy: An Active Approach to Word Learning. Journal of Reading, 27(2), 203-207

Harmon, J. M., Hendrick, \& Wood. (2005). Research on Vocabulary Instruction in the Content Areas: Implications for Struggling Readers. Reading and Writing Quarterly, 21(4),261-80.

Juwita, I. (2013). "Using Vocabulary Self-Collection Strategy (VSS) to Increase Mastery the Junior High School Students' Vocabulary." English Departement Faculty of Language and Arts: Padang State University.

Lester, J. H \& Elliott. (2002). Literary and Learning: Reading in the content areas: Handbook IV for teachers in grades 5.8. Southeastern Louisiana University: Louisiana Public Broadcasting.

Martono, R., A \& Muh, A. (2012). "Improving Students' In Writing Narrative Text Through Animation Movie." English Education Study Program Sebelas Maret University: Surakarta.

Muttahidah. (2012). "Improving Students' Vocabulary Through Vocabulary Card." Department of English Education Faculty of Tarbiyh And Teachers' Training UIN Syarif Hidayatullah: Jakarta.

Safitri, N. F (2015). "Using Vocabulary Self-Collection Strategy (VSS) to Improve Reading Comprehension of The Seventh Grade Student Of SMPN 4 Kalasan in the Academic Year of 2014/2015". English Departement Faculty of Language and Arts: Yogyakarta State University

Stoddard, T. (2006). Vocabulary Self-Collection Strategy with an example from Ender's Game by Orson Scott Card (Online),(http://www.google.co.id/url?q=http://novelinks.org/uploads/Novels/ EnderGames/vocabular_elf.pdf. Accessed on March 16, 2017). 